\title{
Reactions of winter wheat cultivars to Septoria nodorum Berk.
}

\author{
PIRJO PELTONEN, ${ }^{1}$ SINIKKA KARJALAINEN ${ }^{2}$ \& REIJO KARJALAINEN ${ }^{2}$ \\ ' Department of Crop husbandry, University of Helsinki \\ SF-00710 Helsinki, Finland
}

2 Department of Plant Pathology, University of Helsinki SF-00710 Helsinki, Finland

\begin{abstract}
Twelve Finnish and foreign winter wheat cultivars and breeding lines were evaluated for resistance to Septoria nodorum at seedling and adult plant stage. Flag leaf severity varied between 6.5 and $20 \%$ and ear severity between 2.5 and $10 \%$. In general, CI 13091 and Skjaldar were the most resistant cultivars, while $\mathrm{Hja} \mathrm{21614,} \mathrm{Hja} 21638$, and Hankkijan Ilves were the most susceptible ones. Aura and Mironovskaja 808 were most resistant to ear infection, while Vakka and $\mathrm{Hja} 21638$ were most susceptible. Assessment of susceptibility at the seedling stage was quite well correlated with ratings of adult plants in the field $(r=0.72)$. The correlation between lesion length and seedling plant Septoria severity was moderate $(r=0.68)$. Selection of wheat lines for Septoria resistance is discussed.
\end{abstract}

Index words: winter wheat cultivars, Septoria nodorum

\section{Introduction}

Septoria nodorum Berk., the cause of glume and leaf blotch of wheat, occurs worldwide in wheat growing areas (KING et al. 1983). It is also one of the major wheat diseases in Finland (MäKELÄ 1975). In rainy seasons, Septoria can reduce spring wheat yield by up to $20-35 \%$ in susceptible cultivars (KARJALAinen 1985). Infection apparently also reduces hectolitre weight and thus weakens milling properties (KARJALAINEN et al. 1983). However, recent experiments suggest (Karjalainen \& Salovaara 1988) that severe infection does not necessarily weaken baking properties.
During the past few years, chemical control of Septoria nodorum has become prevalent in Finland. However, genetic resistance to the disease would be a very attractive component of integrated control in terms of economy and simplicity of control (DOODSON 1981, PRIESTLEY \& BAyles 1988). Extensive data (BRON. NIMANN 1975, KRUPINSKY et al. 1977, Jeger et al. 1983, KARJALAINEN 1985) indicate that genetic resistance to Septoria nodorum is available in wheat cultivars and lines. However, this resistance appears to be under polygenic control (SCOTT et al. 1982, KARJALAINEN 1983, Fried \& MEISTER 1987), which makes it 
difficult to incorporate it into breeding lines possessing good combinations of characters. Therefore, successful breeding work requires sensitive tools for the detection of small differences between progenies. Several attempts have been made to develop rapid screening techniques for the detection of resistance to S. nodorum (KARJALAINEN 1985, GrifFiths \& JONES 1987). There are now several reports (Scharen \& Krupinsky 1978, Scharen \& Eyal 1980, Benedikz et al. 1981, KarJalalNEN 1984, JöNSSON 1985) that cultivar differences to $S$. nodorum can be reliably detected at the seedling stage using artificial inoculation.

Previous studies (KARJALAINEN et al. 1983, KarJalainen 1984, 1985) have shown clear differences in resistance to $S$. nodorum between cultivars and lines of spring wheat grown in Finland. However, no information is available on the reactions of winter wheats to $S$. nodorum. This study was designed to provide data on the resistance of winter wheat cultivars and lines to $S$. nodorum both at the seedling and the adult plant stage.

\section{Materials and Methods}

\section{Field experiments}

Field experiments were carried out at Anttila Experimental Farm of the Hankkija Plant Breeding Institute in 1984 and 1985. Twelve Finnish and foreign winter wheat cultivars and breeding lines were sown in a randomized plot $\left(0.6 \mathrm{~m}^{2}\right)$ design with five replications. Standard fertilization treatments were applied.

The plots were artificially inoculated with $S$. nodorum. Inoculum consisted of an aqueous suspension of $10^{6}$ conidia $/ \mathrm{ml}$ obtained as described previously (KARJALAINEN 1985). It was sprayed on the leaves just before ear emergence. The percentage area covered by $S$. nodorum lesions was estimated at intervals on the ears, flag leaves and second and third leaves of twenty main shoots per plot.

\section{Seedling plant tests}

All greenhouse tests were carried out at the University Farm of Viikki in winter 1986/87. The same 12 winter wheat cultivars and lines were grown in the greenhouse in $10 \mathrm{~cm}$ plastic pots. Inoculation was carried out at the two-leaf stage by spraying the plants with a spore suspension of $S$. nodorum $\left(10^{6}\right.$ conidia/ $\mathrm{ml}$ ) containing $0.5 \mathrm{ml}$ 'Tween 20' surfacant per $100 \mathrm{ml}$ of suspension. Plants were then covered with plastic bags to maintain high humidity for infection. The plants were rated after 7 and 9 days for Septoria infection according to percent disease area.

\section{Detached seedling leaf tests}

The same 12 winter wheats were grown in the greenhouse in $10 \mathrm{~cm}$ plastic pots. Detached leaves taken from the two-leaf stage plants were cut into sections of about 4-cm lengths, which were mounted on benzimidazole agar in Petri dishes. A drop of $S$. nodorum inoculum $\left(3 \mu \mathrm{l}, 10^{6}\right.$ conidia/ $\left.\mathrm{ml}\right)$ was placed on the center of each section (KARJALAINEN 1984). Seven and nine days after incubation, the length of the leaf lesions showing brown and yellow discoloration was measured. Eight repetitions of the detached seedling leaf test were conducted.

\section{Results}

In general, disease levels in this experiment were moderate (Fig. 1). Flag leaf severity was $6.5-20 \%$ and ear severity $2.5-10 \%$. According to their level of leaf resistance, the test cultivars and lines can be divided into three major groups. CI 13091 and Skjaldar were clearly the most resistant entries with an average of $7 \%$ infection. Hja 25546, Hja 27187, Mironovskaja 808, Vakka, and Nisu were intermediate with an average infection of 10 $12 \%$. Aura, Linna, $\mathrm{Hja} 21614$, Hja 21638 and Hankkijan Ilves were the most susceptible ones with infection rates ranging between 


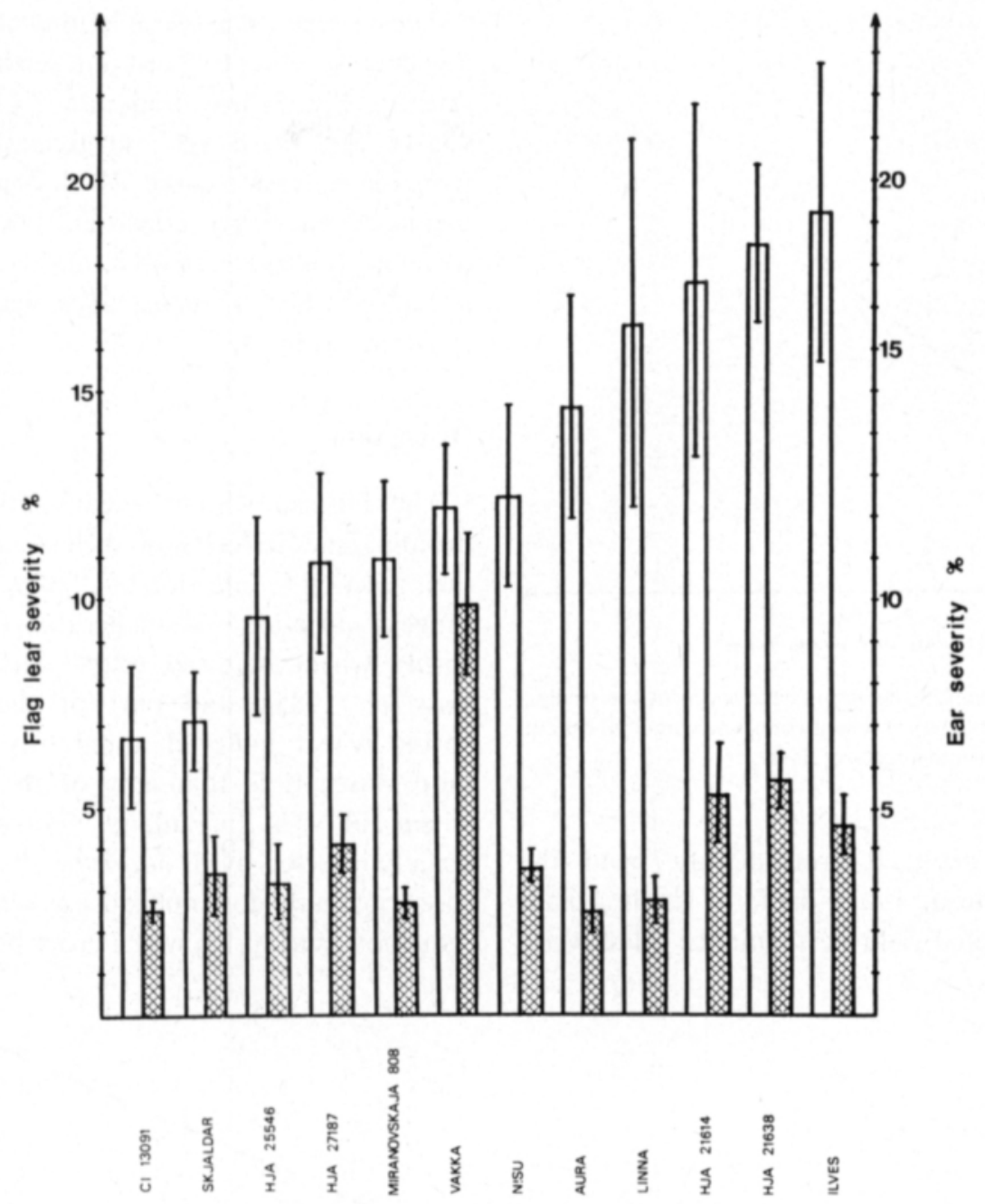

Fig. 1. Susceptibility of winter wheat cultivars and breeding lines to $S$. nodorum as revealed by artificial field inoculation test.

14 and nearly $20 \%$. Ilves showed the most susceptible reaction. However, differences between some of the most susceptible entries were small.

Except for one cultivar, Vakka, there were no major differences in ear severity between the test cultivars and lines. Overall, infection rates were low, most of the cultivars showing an average of less than $5 \%$. The most resistant ones were CI 13091, Mironovskaja 808, and somewhat surprisingly Aura, the leaves of which were rather susceptible. Vakka was the most susceptible cultivar, and it was con- siderably more diseased than the other cultivars, with an average infection of $10 \%$.

There was no consistent correlation between flag leaf and ear severity. CI 13091 was the most resistant one in both respects, and $\mathrm{Hja}$ $21614, \mathrm{Hja} 21638$, and Ilves the most susceptible. However, Aura and Linna, for example, showed quite low infection rates for ear although their flag leaves were very susceptible.

Correlation between the seedling plant test and the adult plant field test (Fig. 2) was moderate $(r=0.72, p<0.01)$, though some 


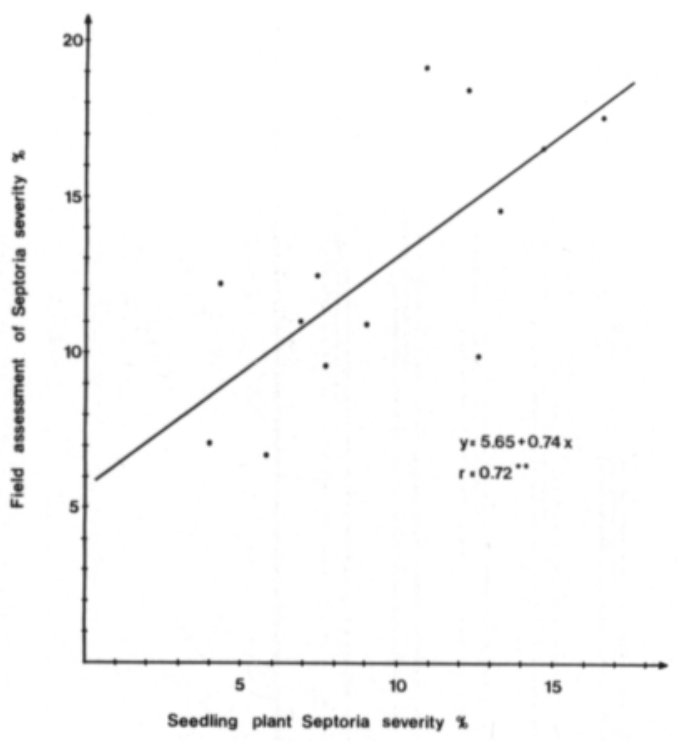

Fig. 2. Relationship between field assessment and seedling plant Septoria severity on some winter wheat cultivars and breeding lines.

cultivars deviated considerably from the general pattern. In our data, the seedling plant test predicted field performance quite well.
The correlation between lesion length in the detached seedling leaf test and seedling plant severity (Fig. 3) was moderate $(r=0.68, p<$ 0.001 ), and there were no great deviations from the regression curve. The lesion development over times was consistent between two different cultivars, Folke and Ilves, and tetraploid wheat $T$. dicoccoides, with varying resistance (Fig. 4).

\section{Discussion}

The Finnish winter wheat cultivars and breeding lines tested showed clear variation in their reaction to infection by $S$. nodorum. The range of variation was smaller than that of the spring wheat material tested earlier (KARJALAINEN 1985), and part of the Finnish spring wheat material apparently is much more susceptible than any of these winter wheat cultivars. In Finland, winter wheat is usually infected by $S$. nodorum, but the disease apparently does not cause as serious yield reduction as to spring wheat crops because the

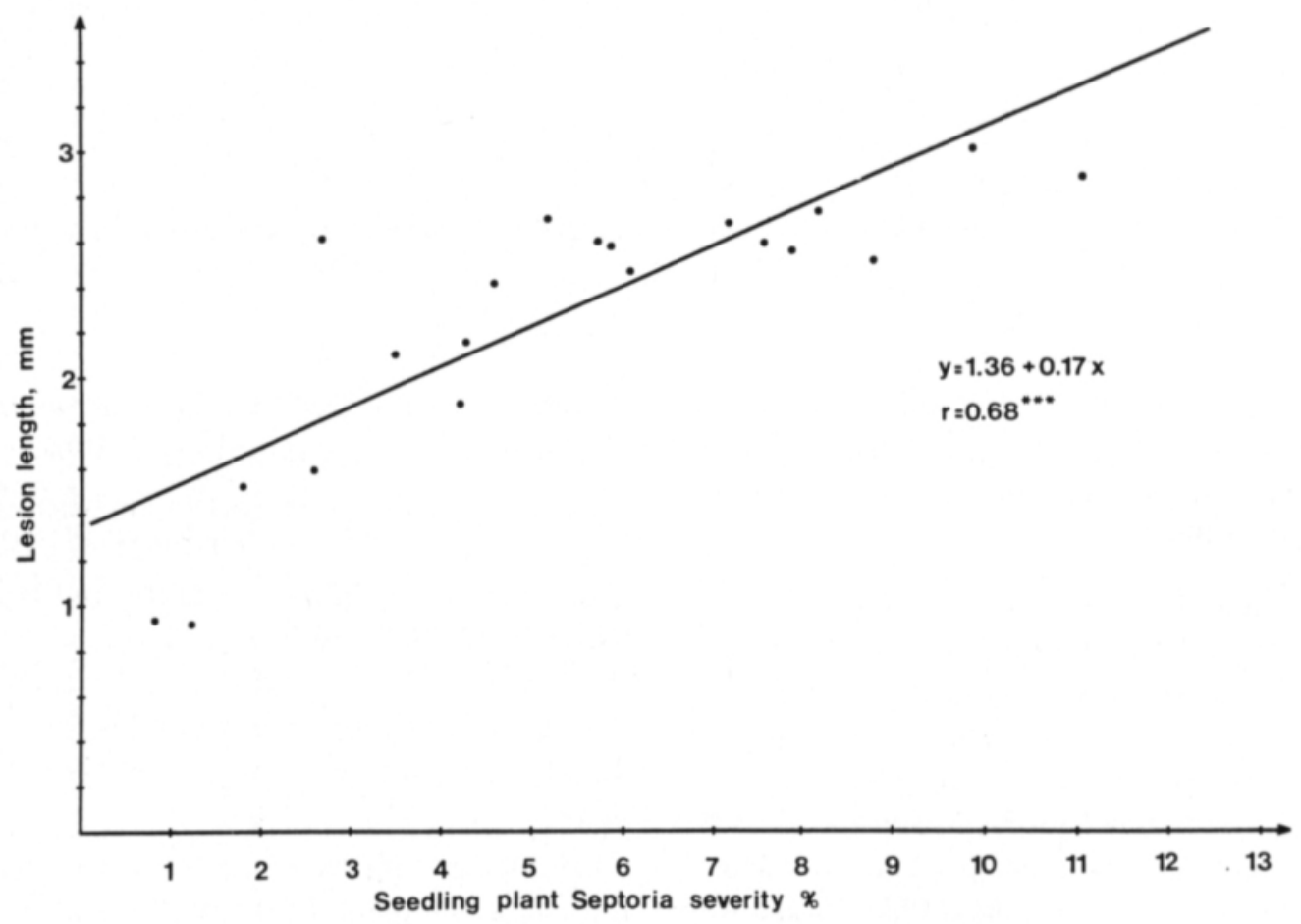

Fig. 3. Relationship between detached seedling leaf test and seedling plant test. 


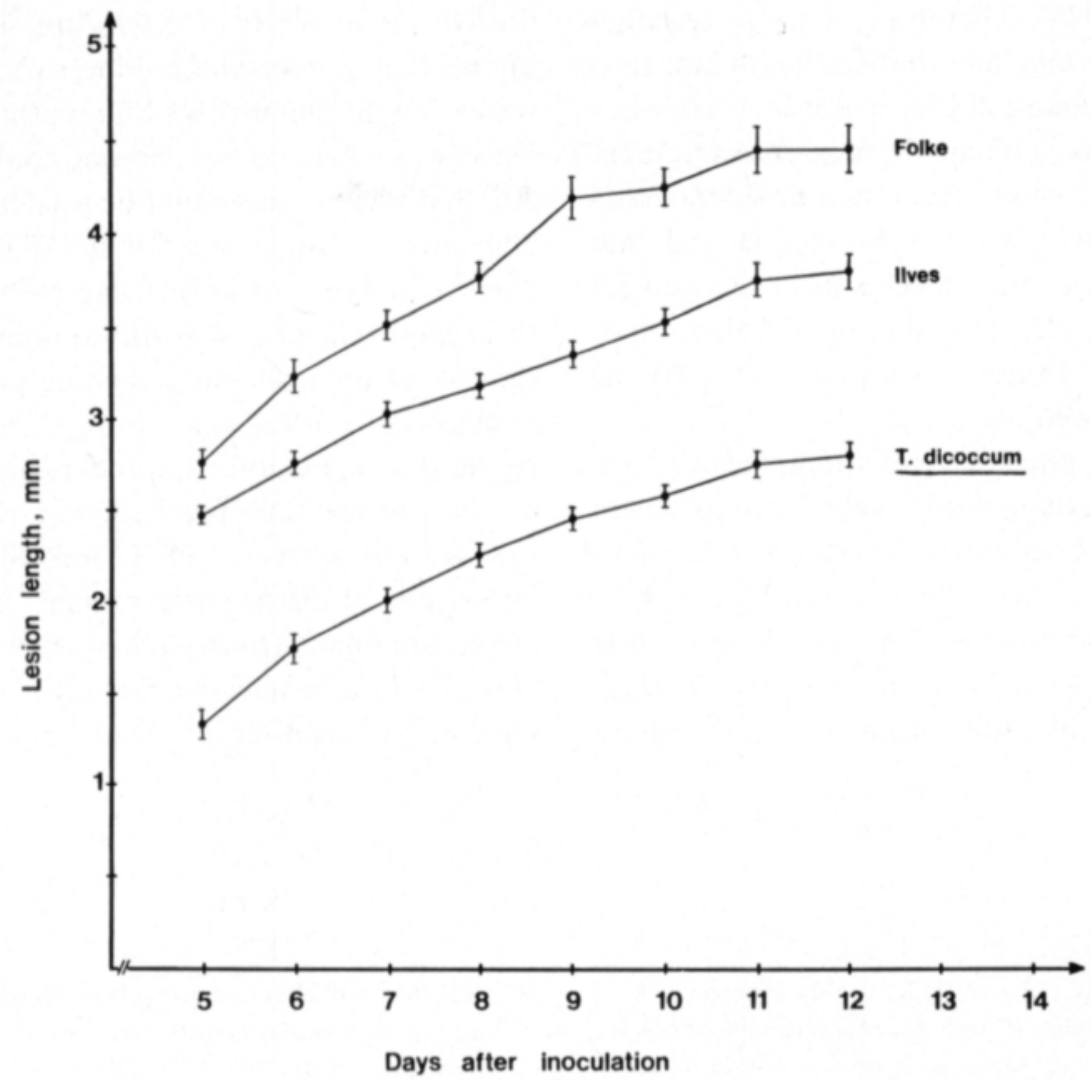

Fig. 4. Disease progress of $S$. nodorum on detached seedling leaves of three winter wheat cultivars in greenhouse tests.

growing period of spring wheat is prolonged towards the end of summer when humidity and the number of rainy days frequently increases thus providing ideal conditions for the rapid spread of $S$. nodorum in wheat canopy.

In our experiment, it was possible to rank the cultivars into three major groups according to their leaf disease severity: the most resistant cultivars, e.g. Skjaldar, intermediately resistant e.g. Hja 25546, Hja 27187, Mironovskaja 808, Vakka and Nisu, and the most susceptible ones e.g. Linna, $\mathrm{Hja} 21638, \mathrm{Hja}$ 21614 and Ilves. The assessment of head disease severity showed only small differences between cultivars, which confirms some previous studies on head reactions to $S$. nodorum (KARJALAINEN 1985). Leaf assessment appears to be a more reliable indicator of cultivar resistance to $S$. nodorum partly because differ- ences between cultivars can be more easily recorded for the leaf than for the ear. It seems evident that head data do not correlate well with leaf data, and recent genetic analyses have indicated (R. Karjalainen \& S. SirkKOMAA, unpublished) that head resistance is a more complicated trait than leaf resistance.

Detection of resistance at the seedling stage appears to be a relatively reliable indicator of cultivar performance in the field. For example, our data show the correlation of $r=0.72$ $(p<0.01)$ between seedling plant assessment and field tests. In addition, the data from detached plant tests also revealed moderately high correlation with field tests. These results are in accordance with previous studies of spring wheat cultivars (KarJaLAINEN 1984, 1985 ) as well as with several other studies (Scharen \& Eyal 1980, Rufty et al. 1981, 
JönSSON 1985). Therefore, it seems reasonably safe to conclude that seedling plant tests can be a valuable aid for wheat breeders when they want to eliminate the most susceptible entries and progenies from their breeding material. However, it must be emphasized that some cultivar may deviate from this general pattern, which means that field evaluation of cultivar resistance is also needed to verify the results of seedling tests.

In recent years, several attempts have been made to develop rapid techniques to screen plant disease resistance. Resistance to $S$. nodorum appears to correlate to some degree with ethylene production of leaves (WENDLAND \& HofFMANN 1987), and this has been considered a possible trait for measuring the quan- titative resistance to $S$. nodorum. It is also known that $S$. nodorum produces some toxins which might be involved in pathogenicity (Kent \& Strobel 1976), and one could speculate that these toxins could be used as a valuable aid in resistance screening (DAUB 1986). Unfortunately, our knowledge of how Septoria causes the disease is still so poor that we cannot set up a reliable screening procedure to detect cultivar resistance using such criteria. In the future, advances in understanding the disease process more precisely (e.g. KARJALAINEN \& LOUNATMAA 1986) and increasing knowledge of disease determinants by utilizing recombinant DNA-techniques will probably give us new sensitive and rapid tools for screening plant disease resistance.

\section{References}

Binidik7, P.W., Scott, P.R. \& Mappledoran, C.J. 1981. A laboratory technique for screening cereals for resistance to Septoria nodorum using detached seedling leaves. Trans. Br. Mycol. Soc. 77: 667-669.

Bronnimiann, A. 1975. Beitrag zur Genetik der Toleranz auf Septoria nodorum Berk. bei Weizen (Triticum aestivum). Z. Pflanzenzüchtg. 75: 138-160.

Dsuв, M.E. 1986. Tissue culture and the selection of resistance to pathogens. Ann. Rev. Phytopathol. 24: $159-186$.

Doobson, J.K. 1981. The economic contribution of resistant winter wheat varieties. J. Natn. Inst. Agric. Bot. 15: $413-420$.

Frite, P.M. \& Mistik, E. Inheritance of leaf and head resistance of winter wheat to Septoria nodorum in a diallel cross. Phytopath. 77: 1371-1375.

Grifriths, H.M. \& Jonts, D.G. 1987. Components of partial resistance as criteria for identifying resistance. Ann. Appl. Biol. 110: 603-610.

Jegier, J.J., Jones, D.G. \& Griffiths, E. 1983. Components of partial resistance of wheat seedlings to Septoria nodorum. Euphytica 32: 575-584.

Jonsson, J.O. 1985. Evaluation of leaf resistance to Septoria nodorum in winter wheat at seedling and adult plant stage. Agri Hortique Gen. 43: 52-68.

KARJALAINEN, R. 1983. Inheritance of leaf resistance to Septoria nodorum Berk. in two crosses of spring wheat. J. Scient. Agric. Soc. Finl. 55: 525-530.

- 1984. Evaluation of detached seedling leaves for use in screening spring wheat cultivars to Septoria nodorum Berk. Acta Agric. Scand. 34: 386-390.
- 1985. Host-pathogen interaction between spring wheat and Septoria nodorum with reference to resistance breeding. J. Agric. Sci. Finl. 57: 1-66.

-, Laitinen, A. \& Juutı, T. 1983. Effects of Septoria nodorum Berk. on yield and yield components of spring wheat. J. Scient. Agric. Soc. Finl. 55: 333-344.

- \& Lounatian, K. 1986. Ultrastructure of penetration and colonization of wheat leaves by Septoria nodorum. Physiol. Mol. Plant Pathol. 29: 263-270.

- \& SAIONAMRA, H. 1988. Effect of severe infection with Septoria nodorum on spring wheat quality. Acta Agric. Scand. 38: 183-188.

Kint, S.S. \& Stroве , G.A. 1976. Phytotoxin from Septoria nodorum. Trans. Br. Mycol. Soc. 67: 354-358.

King, J.E., CoOk, R.J. \& Mtıviı, S.C. 1983. A review of Septoria diseases of wheat and barley. Ann. Appl. Biol. 103: 345-373.

Krupinski, J.M., Cradidock, J.C. \& Scharen, A.L. 1977. Septoria resistance in wheat. Plant Dis. Reptr. 61: $632-636$.

Мікыл, K. 1975. Occurrence of Septoria species on cereals in Finland in 1971-1973. J. Scient. Agric. Soc. Finl. 47: 218-244.

Pritstiey, R.H. \& Builes, R.A. 1988. The contribution and value of resistant cultivars to disease control in cereals. Control of Plant Diseases: Costs and Benefits, ed. Clifford, B.C. Lester, E. p. 53-65. Blackwell Scientific Publications, Oxford.

RuFt, R.C., Hebert, T.T. \& MUrphs, C.F. 1981. Evaluation of resistance to Septoria nodorum in wheat. Plant Dis. 65: 406-409. 
Scharen, A.L. \& Eyal, Z. 1980. Measurement of quantitative resistance to Septoria nodorum in wheat. Plant Dis. 64: 492-496.

- \& KRUPINSKr, J.M. 1978. Detection and manipulation of resistance to Septoria nodorum in wheat. Phytopath. 68: 245-248.

Scott, P.R., Benedikz, P.W. \& Cox, C.J. 1982. A genetic study of the relationship between height, time of ear emergence and resistance to Septoria nodorum in wheat. Plant Path. 31: 45-60.

Wendland, M. \& Hoffmann, G.M. 1987. Nachweis der quantitativen Resistenz von Weizengenotypen gegen Septoria nodorum durch Bestimmung der postinfektionellen Ethylenbildung. Z. PflanzenKrankh. PflanzenSchutz 94: 561-571.

Ms received November 10, 1988

\title{
SELOSTUS
}

\section{Syysvehnälajikkeiden Septoria-taudin \\ kestävyys}

\author{
Pirjo Peltonen, Sinikka Karjalainen ja \\ Reijo Karjalainen
}

Tutkimuksessa tarkastellaan kahdentoista koti- ja ulkomaisen syysvehnän Septoria-taudinkestävyyttă taimija myöhäisvaiheessa. Kasvit saastutettiin keinotekoisesti Septoria nodorum-sienellä ja tautisuusaste arvioitiin prosentteina lehden ja tăhkän pinta-alasta. Taimivaiheen saastunta-astetta tutkittiin kasvihuoneessa taimi- ja lehdenpalatesteillă.

Lippulehden tautisuusaste oli $6.5-20 \%$ ja tăhkăn

$2.5-10 \%$. Cl 13091 ja Skjaldar olivat kestävimmăt koejäsenet ja Hja 21614, Hja 21638 ja Hankkijan Ilves altteimmat. Tăhkä- ja lehti-infektion mäărăt eivăt korreloineet selvăsti. Taimi- ja lehdenpalatestit sekä kenttătestit korreloivat varsin hyvin, samoin taimi- ja lehdenpalatestit, mikã osoittaa, ettă kasvihuonetestejă voidaan käyttäă altteimpien ja kestävimpien lajikkeiden ja linjojen nopeaan alkuseulontaan. 